\title{
Internationalization of Higher Education: A Perspective from the Great South
}

\author{
Marilia Costa Morosini' ${ }^{1}$, Marilene Gabriel Dalla Corte ${ }^{2}$, Alexandre Guilherme ${ }^{1}$ \\ ${ }^{1}$ Pontifícia Universidade Católica do Rio Grande do Sul, Porto Alegre, Brazil \\ ${ }^{2}$ Universidade Federal de Santa Maria, Santa Maria, Brazil \\ Email:alexandre.guilherme@pucrs.br
}

How to cite this paper: Morosini, M. C., Corte, M. G. D., \& Guilherme, A. (2017). Internationalization of Higher Education: A Perspective from the Great South. Creative Education, 8, 95-113. http://dx.doi.org/10.4236/ce.2017.81008

Received: December 1, 2016

Accepted: January 14, 2017

Published: January 17, 2017

Copyright ( $\odot 2017$ by authors and Scientific Research Publishing Inc. This work is licensed under the Creative Commons Attribution International License (CC BY 4.0).

http://creativecommons.org/licenses/by/4.0/

(c) (i) Open Access

\begin{abstract}
It is our contention in this article that the Great South tends to understand the process of internationalisation of Higher Education in terms of "mobility" whilst the Great North, which gave birth to the notion and therefore has greater experience of the process, understands internationalisation in terms of Global Citizenship Education. Mobility is a well-established feature of Higher Education in the Global North (e.g. the Erasmus and Erasmus+ programmes in the EU) but the North understands it as a component of internationalisation and not its summation as in the South. Within this context, we analyse the academic discourse on internationalisation from Brazil, particularly dissertations and theses from Master and $\mathrm{PhD}$ students, which have been logged in a national databank encompassing all subjects. As such, the findings in this databank reflect the research tendencies of young academics, postgraduate courses and departments as well as the perspective of established Brazilian academics who supervised these young scholars.
\end{abstract}

\section{Keywords}

South-South Relations, North-South Relations, Mobility, Brazil, Higher Education

\section{Introduction}

International organisations have continuously emphasised the importance of Higher Education Institutions for global development. In the World Conference on Higher Education (WCHE)/UNESCO in Paris (1998), it was determined that there was a need for the internationalization of Higher Education Institutions at a global level in order to tackle and reduce the differences between developed and emerging countries. This was (and is) to be done through the transfer of theoretical and technological knowledge, which requires the establishment of 
networks and consortiums to allow partners to work together closely and expanding intercultural understanding at the same time. Higher Education Institutions play a significant, if not pivotal role in this, because of they are essentially a public good, and as such are instruments for social and economic changes and development (WCHE, 1998). We quote:

The international dimension of higher education is an inherent part of its quality. Networking, which has emerged as a major means of action, should be based on sharing, solidarity and equality among partners. The "brain drain" has yet to be stemmed, since it continues to deprive the developing countries and those in transition, of the high-level expertise necessary to accelerate their socio-economic progress. Priority should be given to training programmes in the developing countries, in centres of excellence forming regional and international networks, with short periods of specialized and intensive study abroad (WCHE, 1998: p. 2).

Given the importance and impact that the process of internationalization of Higher Education has had on universities, and consequently on the wider society, there is a need to understand how the process is being conceived and implemented throughout the world. In this article, we argue that there are substantial differences between undertakings in the Global North and the Global South. It is our contention that the Great South tends to understand the process of internationalisation of Higher Education in terms of "mobility" whilst the Great North, which gave birth to the notion and therefore has greater experience of the process, understands internationalisation in terms of Global Citizenship Education.

This article is divided into two main sections. Firstly, we discuss the concept of internationalization from the perspective of the Great North, and as a follow up from this, how internationalization is being understood in the Great South, particularly Brazil. Secondly, we analyse the academic discourse on internationalisation from Brazil, particularly dissertations and theses from Master and $\mathrm{PhD}$ students, which have been logged in a national databank encompassing all subjects. As such, the findings in this databank reflect the research tendencies of young academics, postgraduate courses and departments as well as the perspective of established Brazilian academics who supervised these young scholars. We conclude by arguing that the Great South must seek neither to encourage academic mobility alone nor continue with the focus of South-South regionalism, but must place itself truly on the global stage, forming networks, encouraging Global citizens and in so doing, embedding itself fully into the very nature of the process of internationalization of Higher Education, well beyond the restrictive notion of academic mobility alone.

\section{Internationalization-A Perspective from the Global North}

We note that there is a considerable amount of theoretical work on the concept of internationalization of Higher Education in the Great North (Knight, 2004; 
Knight, 2005) and this has affected socio-political agendas in developed counties. This process seems to be more advanced and developed in Europe and thus we will use its experience as a core example and background to our discussion. For instance, it could be said that the idea of internationalisation of Higher Education has contributed to the construction of the European Union through an understanding that goes beyond economics and that embraces the idea of European citizens byway of educational ventures. For almost thirty years, "the European Union (EU) has been systematically promoting student mobility within Europe. Through the "European Action Scheme for the Mobility of University Students" (ERASMUS), the largest student exchange programme in Europe, nearly two million students have studied abroad and had the opportunity to learn firsthand about other European peoples and cultures" (Sigalas, 2009: p. 2). This is based on a "premise [that] draws on Karl Deutsch's theory, according to which increased cross-border people mobility is one of the essential conditions for the success of international integration and the formation of a "we-feeling" among different peoples (Deutsch et al., 1968). Thus, if we take into account that living abroad is more likely to have a greater impact on one's personality the younger one is, it comes as no surprise that European student mobility is widely seen as an instrument that promotes a common European identity (e.g. Fligstein, 2008; Green, 2007; Wallace, 1990)" (Sigalas, 2009: p. 2). A recent document from the European Union, The Development of European Identity/Identities: Unfinished Business, confirms this when it states:

$[\mathrm{T}] \mathrm{o}$ establish that the impetus behind some people moving against the prevalent inertia of the general population and spontaneously developing a real sense of themselves as a European was neither the Erasmus educational exchange they had as a young adult, nor their experience of seeking and finding employment in another country, nor the appeal of higher European ideals, but instead that the real spark was meeting and forming a close relationship with someone from another country (European Union, 2012: p. 36).

Given that not all students and staff take the opportunity to have an experience abroad, that is, do not engage in "mobility", a new related conception of internationalization has emerged: internationalization at home. This means that institutions must encourage staff and students to gain an understanding of intercultural issues and respect for diversity (Haug, 2010) in their home institution. In relation to this, Robson (2011: p. 621) draws our attention to the opportunity for developing a transformative agenda "that creates new challenges and opportunities for universities to engage all stakeholders in the "radical reassessment of the purposes, priorities and processes" of HE (De Vita \& Case, 2003: p. 383 ) that delivering a world class internationalized education requires. Internationalization can act as a descriptor of the institutional culture, illustrating the ways in which the ethical and ideological values and beliefs represented by its communities underpin program design, curriculum delivery and teacherstudent relationships"; and Freeman et al. (2008) emphasise that this is an op- 
portunity to develop intercultural competences through education, which they defined as "a dynamic, ongoing, interactive self-reflective learning process that transforms attitudes, skills and knowledge for effective communication and interaction across cultures and contexts" (Freeman et al., 2008: p. 13). Thus, we argue that internationalization at home means providing intercultural education, which is the kind of education that is characterised by an awareness of possible challenges but also of its possibilities. We quote:

Although the concerns for these challenges, and sometimes difficulties, of internationalisation must be taken into account early enough, the conflict approach to cultural diversity seems to be a misleading track for institutional development. The fundamental and more cooperative assumption of "internationalisation at home" as a means for mutual intercultural learning is to consider cultural diversity as a general resource and potential enrichment. Intercultural learning, although a process of individual development, cannot be left to the initiative of individuals alone. Rather, it should be inherent to education and educational institutions. A valuing approach to cultural differences should be an integrated dimension in curriculum development, teaching and all other social and organisational activities of educational programmes. With this notion, intercultural learning is both continuous effort and educational outcome of internationalisation at home (Otten, 1999: p. 19).

All of these recent developments in the Global North have directed the process of internationalization of Higher Education, and research into this process, towards the formation of dynamic networks of collaboration and joint-research efforts between scholars and institutions as well as cross-border funding of research activities by internationally recognised consortiums (OECD 2008; OECD 2012). This process also involves the internationalization of the curriculum and syllabus by providing students with the opportunity to experience issues through a global perspective, identifying "hot topics" which are being internationally discussed in their respective fields, and attain an intercultural and multicultural understanding (Leask et al., 2013; Nilsson, 2000; Clifford, 2013). And the WCHE (1998: p. 1) states that "to achieve this goal, curricula need to be recast so as to go beyond simple cognitive mastery of disciplines and include the acquisition of skills, competencies and abilities for communication, creative and critical analysis, independent thinking and team work in multicultural contexts".

These features are also reflected in the recent document by the European Union, Internationalization of Higher Education, which underlines the importance of the role played by institutional policies, to be understood both at the macro (e.g. OECD; EU) as well as at the micro level (i.e. particular Higher Education institutions), in directing the process of internationalization towards mobility, collaboration and networking, and changes in the curriculum. We quote:

The motive behind most institutional policies that mention internationalisation is the desire to prepare graduates for participation in a globalised 
work force or to create global citizens able to interact with peoples from different cultures. International student and staff mobility, international collaboration (research and double degree programmes) ... the creation of the international classroom, or internationalisation of the curriculum are among the institutional activities mentioned that are geared to achieving the desired internationalisation outcomes (our emphasis) (European Union, 2015: pp. 130-131).

This means that the management of Higher Education institutions and policy makers play a fundamental role in the implementation of the process of internationalization in education. Their understanding of the term internationalization as well as of the directives guiding the implementation of policies on internationalization is crucial for the whole process, determining its development and outcomes.

Hence, initially the conception of internationalization was directed at teaching-and-learning and sought to enable the "free circulation" of diplomas and degrees; that is, the mutual acceptance of these by various partner countries. Alongside this, emerged the project of student and staff mobility (e.g. ERASMUS) which has become an object of study itself giving rise to societies (e.g. EAIE), journals (e.g. IJHE), and a number of events as well as formal and informal networks. These two initial stages have now given rise to a third, very important one; that is, internationalization is now being conceived of in different terms due to the process of globalization and the weakening of the role of nation-states as well as of regional blocks. This means that internationalization is now expanding from the local to the world, from the idea of European citizens to that of Global citizens. This development is also emphasised in actions by multilateral organisations such as the World Bank, OECD and UNESCO (Lazaro, 2016). We quote a recent document by the European Union, Internationalization of Higher Education, which corroborates this:

The scenario envisages that, if the barriers are removed and the enablers activated, a European higher education will emerge whose graduates will be able to contribute meaningfully as global citizens and global professionals in a Europe that is better placed not only to compete but also to cooperate (our emphasis-European Union, 2015: pp. 28-29).

This leads us to ask the question: What is Global Citizenship Education? There is a great deal of discussion around the concept of Global Citizenship Education (GCE) with some defining it as "citizenship beyond borders" (Weale, 1991), "citizenship beyond the Nation-State" (Bellamy, 2000), as a sort of "cosmopolitanism" (Keck \& Sikkink, 1998; Appiah, 2008), or even as the kind of awareness that gives rise to "planetary citizenship" and the responsibility to look after the Earth (Henderson \& Ikea, 2004) (cf. UNESCO, 2014: p. 14). However, it is the following definition that seems to really encapsulate the kind of education that focus as on GCE:

[h]ighlights essential functions of education related to the formation of 
citizenship with globalization. It is a concern with the relevance of knowledge, skills and values for the participation of citizens in, and their contribution to, dimensions of societal development which are linked at local and global levels. It is directly related to the civic, social and political socialization function of education, and ultimately to the contribution of education in preparing children and young people to deal with the challenges of today's increasingly interconnected and interdependent world (Tawil, 2013; cf. UNESCO, 2014: p. 15).

This means that for GCE to take place there must be a focus on "student experience" at home and abroad, which implies not just inbound/outbound mobility but also a curriculum and syllabus encouraging students to attain "knowledge, skills and values for...participation [as] citizens, contribut[ing] to dimensions of societal development ... at local and global levels" (UNESCO, 2014: p. 15). In Global Citizenship Education: preparing learners for the challenges of the $21^{\text {st }}$ century the UNESCO (2014: p. 22) presented the following scheme, which is centred around the ideals of dialogue, critical thinking, holism and values, as a way of visualising Global Citizenship Education (GCE) (Figure 1):

\section{Internationalization-A Perspective from the Great South}

Research into the process of internationalization in the Great South has been growing steadily, however, it is still very timid if we compare it to the Great

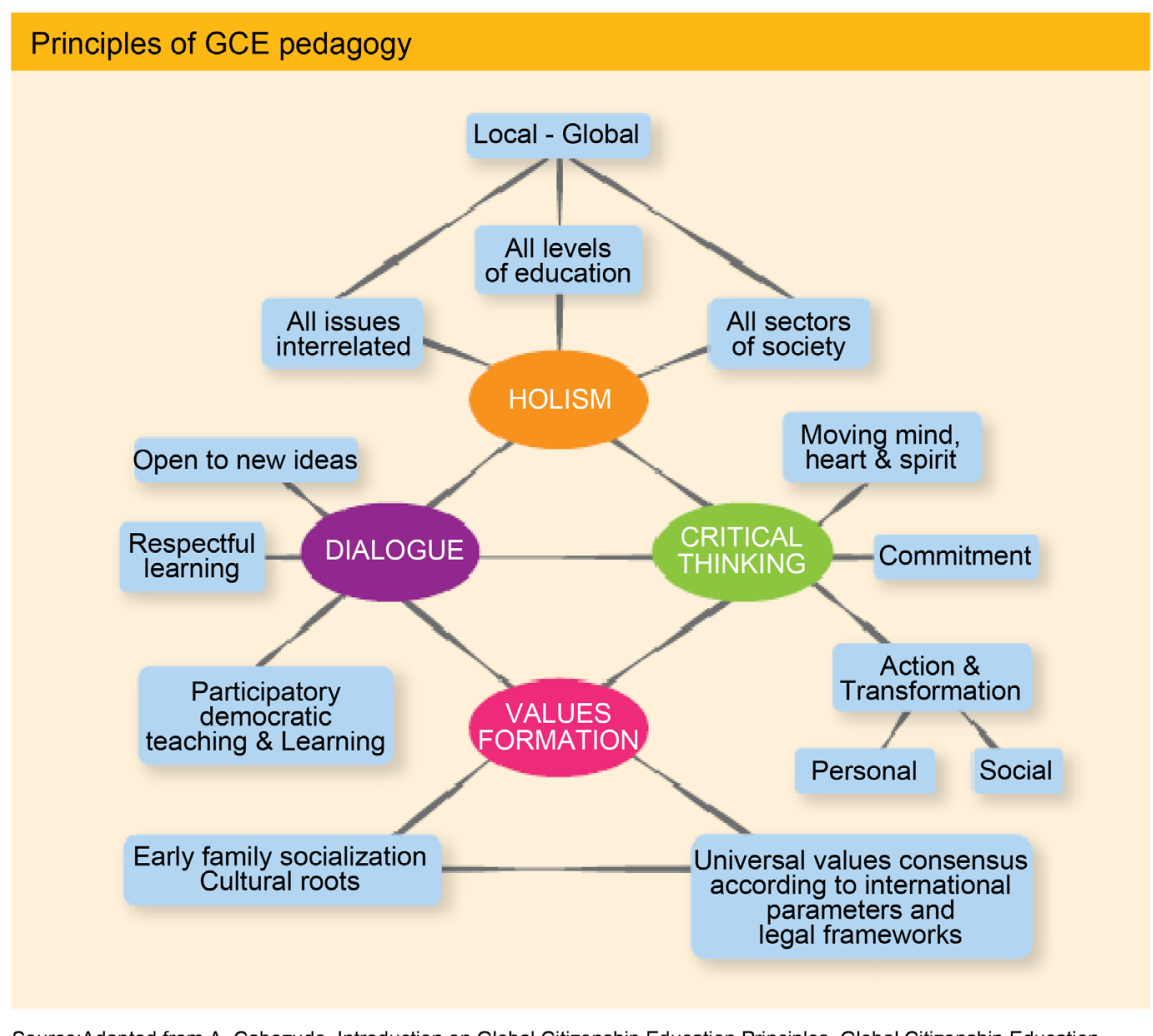

Source:Adapted from A. Cabezudo. Introduction on Global Citizenship Education Principles. Global Citizenship Education Forum, Bangkok, Thailand, December 2013.

Figure 1. Principles of GCE pedagogy. 
North (Aupetit \& Escobar, 2014; Morosini, 2015). This process is being driven by the strong arm of the state through government evaluations of quality of education and provision in Higher Education institutions, and amongst its most important criteria is internationalization. In Brazil, Higher Education is extremely centralized and controlled by the Federal government as the state determines educational policies and the process of evaluating institutions; it also has a strong say in the management of Federal Higher Education institutions throughout the country. Policies and regulations are usually implemented through regulating agencies such as CAPES (i.e. Coordination for the Improvement of Higher Education Personnel), which is a foundation directly connected to the Ministry of Education, and CNPq (i.e. Council for Scientific and Technological Development), which is an agency under the Ministry of Science, Technology, Innovation and Communication.

In Brazil, internationalization has become a key-feature and criteria for the evaluation of postgraduate programmes, and it is expressed as cooperation through academic mobility (e.g. fellowships to spend time at Higher Education institutions abroad; visiting fellowships for academics from Higher Education institutions abroad to spend time in Brazilian universities). Undergraduate programmes do not have their evaluations clearly defined by an internationalization criterion, however, in 2011 the Federal government implemented a mobility programme for science undergraduates to spend one year abroad-this programme is called Science without Borders (Ciênciassem Fronteiras). Besides this understanding of internationalization as mobility, there are some funding opportunities from CAPES, CNPq, and other agencies, which are extremely competitive and geared towards the sciences, for collaboration with and the implementation of projects with international partners. As it can be gathered, in the Great South, if we take the case of Brazil as a general example, internationalization seems still to be understood mainly as mobility and there is a clear tendency to privilege the sciences over the arts and humanities; however, a timid movement towards wider collaboration and formation of networks seems to be emerging.

As such, it is our contention that the Great South tends to understand the process of internationalisation of Higher Education in terms of "mobility" whilst the Great North, which gave origin and has experienced the process, now understands internationalisation in terms of Global Citizenship Education. We believe that the main reason for this is that Global North's experience of internationalisation of Higher Education over a longer period of time, and the fact that mobility is a well-established feature of-Higher Education in the Global North (e.g. the Erasmus and Erasmus+ programmes in the EU).

Further, it is argued that in the Great South the internationalization of Higher Education has adopted the principle that it must be based on cooperation, solidarity and exchange of knowledge, so to strengthen Latin American and Caribbean institutions in terms of science and technology and meeting the challenges of development and overcoming social inequalities (Declaration of Foz do Iguazu, 
2015: p. 343). That is, there is a more regional focus rather than a global one in the Great South. As we have already mentioned, this understanding of internationalization has led the Brazilian government to interfere directly in the process of internationalization of Higher Education in the country. As such, the "Brazilian government policies interfere in Brazilian academic outputs. Recently and because of worldwide changes caused by the process of globalisation, these policies have sought to develop a multilateralism, developing various South-South partnerships with other important semi-peripheral countries (i.e. South Africa, China, India) as well as with other Latin American countries, particularly the Mercosur" (our translation) (Menezes \& Ribeiro, 2011: p. 4). This demonstrates that Brazil has been prioritising developing South-South relations, encouraging mobility with other South partners, and it could be suggested that the formation of networks and the pursuit of global citizenship is still very much in its infancy. However, it is important to note that South-North mobility is still very substantial, especially due to mobility programmes, such as the already mentioned Science without Borders (Ciênciassem Fronteiras) for undergraduate students, and other such programmes at postgraduate level.

\section{Internationalization of Higher Education-The Current State of Affairs in Brazil}

Within this context, we analyse academic outputs on internationalisation from Brazil, particularly dissertations and theses from Master and $\mathrm{PhD}$ students, which are logged in a national databank encompassing all subjects. As such, findings in this databank reflect the research tendencies of young academics, postgraduate courses and departments as well as the perspective of established Brazilian academics who supervised these young scholars.

The following keywords were used in the search engine Biblioteca Digital Brasileira de Teses e Dissertações (i.e. Brazilian Digital Library of Theses and Dissertations-Available on: "http://bdtd.ibict.br/vufind/"): 1) internacionalização da Educação Superior (internationalization of Higher Education) yielding 14 results; 2) internacionalização e Educação Superior (internationalization and Higher Education), which resulted in 27 works; and 3) internacionalização, educação superior e globalização (internationalization, Higher Education and Globalization), with 11 works. That is, a total of 52 works were found and 22 (i.e. 14 dissertations and 8 thesis; Figure 2) were selected for analysis as they were directly connected to the topic of internationalization and higher education.

Further, the vast majority of theses and dissertations produced in Brazil that focus on the processes of internationalization of Higher Education are centred around the "mobility" theme. It also verified that this topic, namely mobility, is usually discussed in connection to "institutional strategies", "accreditation", and "international cooperation", always having North-South and South-South relations as its background. This means that mobility is the main driver of the process of internationalization in Brazil. 


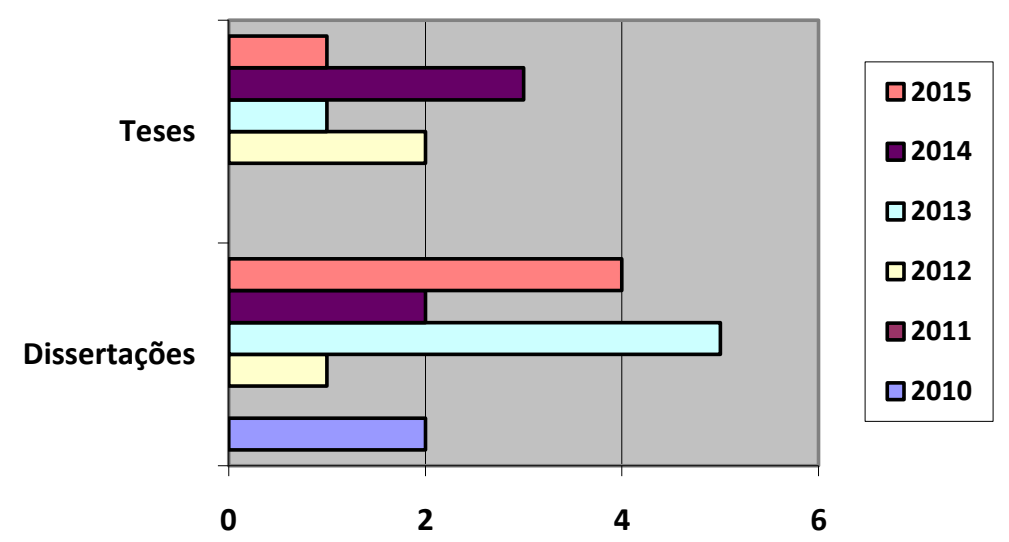

Figure 2. Theses and dissertations dealing with the topic of internationalization of higher education-2010 to 2015. Source: Authors.

It is also important to emphasise that dissertations and theses seem to suggest that Brazilian universities have been investing in internationalization, allocating significant resources to their strategic planning. This occurs in relation to both the Global North and the Global South. In this respect, the following are some core factors related to the institutionalization of internationalization in Higher Education that are present in the analysed dissertations and theses:

1) Available places are equally divided between undergraduate foreign students and visiting scholars.

2) Undergraduate students tend to spend six to twelve months in mobility, and there is a perceptible move towards the longer period of time taken.

3) Places are being specially allocated in universities and careful attention is given in order to guarantee the right conditions to receive foreign students and visitors, so that they remain for the whole and intended period of their stay.

4) Considering ways to make access to degrees more flexible, such as through transferring credits and validation of certificates and diplomas, facilitating mobility and encouraging integration.

5) Implementation of programmes such as Programas de Estudantes-Convênio de Graduação (PEC-G-undergraduate academic mobility programme for Latin American and African students to come to Brazil) ouPós-graduação (PECPG-postgraduate academic mobility programme for Latin American and African students to come to Brazil), which have the support of the Ministry of Foreign Affairs and the Ministry of Education. PEC-G.

6) Establishment of the Office of Foreign Affairs, which is responsible for the implementation of Bilateral Agreements and Memorandums of Understanding with other partner universities.

7) Development of international partnerships and exchanges, encouraging academic staff to pursue pos-docs abroad and to publish in international journals.

8) Apply guidelines by international and multilateral organisations at a managerial level and in evaluation mechanisms.

9) Effect a cultural change through different infrastructures and global trends 
so to improve administration, financial health and performance of the organisation.

It is evident from these 9 factors that the central feature of internationalization in Higher Education as understood in Brazil is mobility with some efforts towards the formation of networks, and thus it is somewhat lagging behind in its understanding if compared to the Global North, who is now pursuing the idea of global citizenship. Moreover, and on further analysis, it was established that mobility is following two distinct routes: South-South and South-North (Figure 3 and Table 1).

\section{South-South Mobility}

Our findings demonstrate that $36.4 \%$ of all dissertations and theses dealing with internationalisation of Higher Education in Brazil in the period 2010-2016 focus on the South-South academic mobility. This seems to suggest that Brazil is investing in actions seeking cooperation and integration with other Latin American countries; that is, seeking "to insert itself in the international arena as a country whose attributes place it on an intermediate scale between the least and

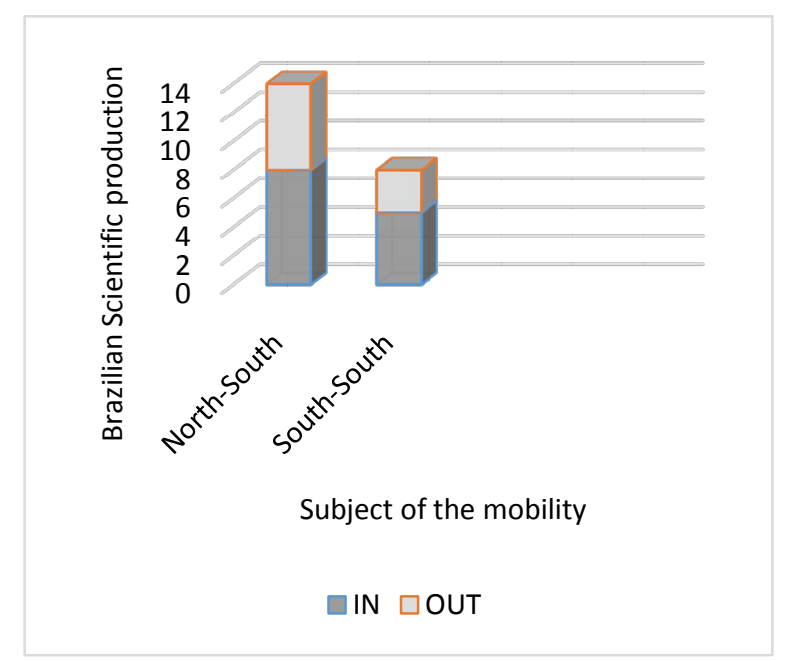

Figure 3. Brazilian theses and dissertations and the academic mobility direction. Source: Authors.

Table 1. Focus of higher education mobility.

\begin{tabular}{ccc}
\hline Focus of the mobility & $\mathrm{N}^{\circ}$ & $\%$ \\
North-South & 14 & 63.6 \\
North-South (in) & 8 & 36.4 \\
South-North (out) & 6 & 27.3 \\
South-South & 8 & 36.4 \\
South-Brazil (in) & 5 & 22.7 \\
Brazil-South (out) & 3 & 13.6 \\
Total & 22 & 100 \\
\hline
\end{tabular}

Source: Authors. 
most powerful" (our translation) (Brackman, 2010: p. 90). The following is a list of the core themes related to South-South relations that are dealt with in the dissertations and theses analysed:

1) Creation of a new university that will foster regional integration (UNILAUniversidade Federal da Integracao Latino Americana).

2) Latin American universities: processes of expansion and internationalisation.

3) Programmes of Educational and International Cooperation between Brazil and PALOP (Portuguese language countries).

4) International migration and the issue of identity: Undergraduate students from PALOP (Portuguese language countries).

5) Academic mobility within MERCOSUR.

6) PEC-G (undergraduate academic mobility programme for Latin American and African students to come to Brazil).

7) PEC-PG (postgraduate academic mobility programme for Latin American and African students to come to Brazil).

According to the 7 themes mentioned above inbound mobility is a very important feature of internationalisation in Higher Education in Brazil. This seems to be a particularly relevant point concerning Portuguese-speaking African countries (PALOP) (i.e. Angola, Mozambique, Cape Verde, Guine-Bissau and Sao Tome e Principe). Rodrigues (2013: p. 3) corroborates this when stating that "it is necessary to reflect upon and improve actions of international cooperation in education with PALOP countries so that they go beyond the mere allocation of places in universities and start providing the right conditions to receive these students, guaranteeing their permanence". That is, there is a need to improve retention and permanence of foreign students in Brazilian universities, and we would go further, to encourage the formation of networks and consortiums for the development of joint research projects.

In this connection, one of the works refers to the Programa de Cooperacao International do Governo Brasileiro para Capacitacao de Professores de Mozambique (Program of International Cooperation by the Brazilian Government for Teacher Development in Mozambique), which was done through the Universidade Aberta do Brazil (UAB-Brazilian Open University) and through distance learning. The Programa UAB/Mozambique sought to build South-South cooperation and focused on the professional development of teachers in Higher Education. This project was conceived in order to aid Mozambique to become better equipped to develop and advance their educational system (cf. Jesus, 2015), demonstrating that Brazil is trying to transfer knowledge and position itself as a potential and credible research partner.

It is interesting that two of the dissertations and thesis, which were analysed focused on the traditional programs of inbound mobility PEC (Programa Estudante Convenio) from the Ministry of Foreign Affairs and Ministry of Education, which was created more than 50 years ago to fund undergraduate and postgraduate students from other Latin American and African countries to come 
to Brazil. As a result of the study of the PEC-PG (i.e. postgraduate) it was established that Latin American students maintain strong intentions to remain indefinitely in Brazil; in contrast to this, African students seek a good standard of education in order to fulfil a sincere desire, when they return home, of helping to improve their respective country (FEIJó, 2013). In another study conducting research into the PEC-G (i.e. graduate), it became evident that the programme is important for developing countries that benefit from it, especially the Portuguese-speaking countries of Africa (i.e. PALOP). Thus, these two recent studies emphasise the importance of South-South relations for Brazil. However, "beyond the implementation of the PEC-G in Higher Education institutions [in Brazil], what is important is to plan actions to welcome and integrate foreign students in the academic space so to help their permanence" (our translation) (Sousa, 2015: p. 8), which once again raises questions about the need of actions for the retention and permanence of foreign students in Brazilian Higher Education institutions. One of the reasons for this, is that mobility is conceived at a macro socio-educational level, but it is regulated and implemented in a particular environment, the Higher Education institution, and experienced directly by students (cf. Santos, 2014: p. 9), creating a gap between theory and practice.

Moving on to studies focusing on Latin American integration, particularly those of Mercosur, we note that one of these conducted research into the Programme ESCALA/AUGM (i.e. Programa Escla de Estudiantesde Grado/La Asociación de Universidades Grupo Montevideo), which aims to expand undergraduate studies so to change one's perspective about Latin America and its universities, which have suffered historically from an "inferiority complex". As such, Costa (2014: p. 9) notes that "mobility within the region and a student's option for Latin America can be understood as an alternative that allows for the experiencing of the South". Further, and in one of the thesis, the notion of regional integration is discussed in detail and this seems to reflect efforts to create a Espacio Lationamericano y Caribeno de Educacion Superior (ELACES-Latin American and Caribbean Higher Education Area), which is founded on two core principles: 1) equality and 2) the necessity to overcome social inequalities. The ELACES also emphasises the importance of national and regional citizenship as a direct alternative to global citizenship. This is so because it understands that subscribing to the project of global citizenship might lead the region to be excluded from transnational elite mechanisms and organisations as well as important decision making processes. The main reason for this is that the ELACES understands that the global context encompass large economic areas that are interconnected, highly competitive and based on asymmetries, and this means that "regional integration is a necessary alternative to reposition and improve national higher education institutions. Integration will contribute to efforts of improving economic competitiveness byway of technological and scientific developments as well as social cohesion within the regional area" (our translationDeclaration of Foz do Iguazu, 2015: p. 343).

It is worth noting that the Brazilian focus on regional integration is directly 
connected to government policy that, following developments in the $21^{\text {st }}$ century, opted to develop multilateral policies. As such, "the development of various South-South partnerships with other important semi-peripheric countries (i.e. South Africa, China, India) as well as with other Latin American, particularly the Mercosur" (our translation-Menezes \& Ribeiro, 2011: p. 4) became a priority for Brazil. The creation of the UNILA (Universidade Federal da Integracao Latino-Americana) is very much the result of this Brazilian foreign policy, which was pursued by Fernando Henrique Cardoso (President between 1995 and 2003), and especially during the two mandates by Luiz Inácio Lula da Silva (President between 2003 and 2010). Thus, the UNILA:

is a hybrid kind of university, contemplating various models but with the exception of the commercial one. However, ... UNILA distance itself from the norm because it seeks to innovate through: interdisciplinary teaching; classes in Portuguese and Spanish; selection of students open to candidates from the various countries of the region; academic staff from all countries of the region; courses that are of interest to the region; emphasis on regional integration; seeking to encourage countries to take part in the international sphere; promotion of values and national interests based on a culture of peace, solidarity and human rights (our translation-Brackman, 2010: p. 91).

Thus, regional exchange and academic mobility, both of students and professors, is a core feature of the UNILA, and it can be argued that this aims at the integration of Latin American countries and forging of a Latin American identity. In a way, the UNILA mirrors in a much smaller scale the European process of integration and rise of the European identity through Higher Education mobility.

\section{South-North Mobility}

An analysis of the dissertations and thesis demonstrated that $63.6 \%$ of them were concerned with South-North mobility. The following is a list of the core themes dealt with in these works:

1) Academic mobility: Brazilian students in European universities.

2) Implementation of a regional curriculum at undergraduate level in the MERCOSUR based on the experiences of the Bologna process.

3) Internationalization of Higher Education in Brazil and the guidelines by multilateral organisations.

4) European students' motivations to come and study in Brazil.

5) Concepts, characteristics and strategies at the heart of the process of internationalization of Higher Education institutions in Brazil.

6) Government influencing internationalization of Higher Education in Brazil through the implementation of programmes, such as Ciênciassem Fronteiras.

7) Government influencing internationalization of Higher Education in Brazil byway of evaluating of postgraduate courses and departments. 
Our analysis seems to support the idea that internationalization of Higher Education in the Great South is still understood mainly in terms of mobility, which is being managed, administrated and implemented in a very specific way. As we noted, there has been a tendency to prioritise relations with countries in the Great South, and particularly Latin America; however, some strong gesture towards countries in the Global North has also been made. Some of the analysed works conducted research into inbound mobility from countries in the Global North to Brazil, and more specifically Sao Paulo, Rio de Janeiro and Belo Horizonte. According to Silva (2013: p. 6):

Academic mobility, a phenomenon moving vast numbers of students beyond their respective home country's borders, is high on the political and academic agenda. It is the most visible feature of the process of internationalization of Higher Education and it is intensifying due to globalization. That said, it is possible to identify asymmetries between sending and receiving foreign students. Brazil does not have a tradition of receiving international students. However, a growing number of students have showed an interest in experiencing life in a Brazilian Higher Education institution (our translation).

And Silva (2013: p. 6) continues affirming that this might be due to:

a desire to learn Portuguese, improve their CVs, and invest in an international career. Brazil has reached a certain status in the international arena, and as such it is perceived as full of potential either as a place to work or to make business with.

In another study entitled "Beyond Sea, Sun and Fun in Rio de Janeiro: Understanding Exchange Students Motivations and Interests", Kling (2013: p. 8) corroborates the above by identifying Global North students' motivations for coming to Brazil, more specifically to Rio, as related to learning the language, improve their $\mathrm{CV}$ and experiencing life in an Emerging country. He says:

The cliché-sun, beach and carnival-manifested itself in several responses, but never as main factor. Students are interested in the city for reasons other than tourism attractions, such as learning Portuguese, improve their $\mathrm{CVs}$ and living in an emerging economy (our translation).

Sena (2013: p. 9) is another relevant study, which conducted research into exchange students at the Universidade de Fortaleza and concluded that taking part in international mobility programs is something very positive for exchange students. This is so because it allows them to "experience different educational settings and systems, learn another language and culture, and deal with different values, all of which influence the development of human and cultural capital" (our translation). This has overtones of Global Citizenship Education, which might suggest that this category has started to emerge in connection to the Great South, and this is a natural development of mobility, and perhaps due to inbound mobility by Global North students and academics. Besides, this is not 
surprising giving that the Great North experienced a similar process, from mobility to formation of networks, to global citizenship. The process should follow the same pathway in the Global South.

Anastácio (2014) provides further evidence that the conception of internationalization in Higher Education in the Great South is developing and starting to encompass the idea of networking and Global Citizenship Education. Anastácio (2014: p. 5) states that, encouraged by national and international policies using government programs that are developed and implemented by universities, "[...] the internationalization of Higher Education is part of the broad process of globalization that instigates the flow of people across national boundaries ... [as such] in contemporary society, the internationalization of Higher Education has fostered new narratives, programs and practices, conferring distinctive credentials to subjects, groups, classes and institutions" (our emphasis).

It is also important to note that the North also influences the South by providing examples from experience in the internationalization of Higher Education. Monteiro (2013) conducted research into undergraduate courses teaching design in the Mercosur, while arguing for regional integration. Monteiro's (2013) proposal is based on the Bologna process, and seeks to identify common elements and implement a similar curricular program for design courses in Mercosur countries. The author interviewed a number of academics in Portugal who participated in the implementation of the Bologna Process in the country, trying to identify positive and negative aspects of the process, which could guide a similar program in Brazil and Mercosur. Following developments in the EU, it is suggested that if a version of the Bologna process was to be implemented in the Mercosur, it would facilitate mobility and increase regional integration, and foster the idea of a Latin American identity.

\section{Conclusion}

It was our contention in this article that the Great South tends to understand the process of internationalisation of Higher Education in terms of "mobility" whilst the Great North, which gave birth to the notion and therefore has greater experience of the process, understands internationalisation in terms of Global Citizenship Education. Mobility is a well-established feature of Higher Education in the Global North (e.g. the Erasmus and Erasmus+ programmes in the EU) but the North understands it as a component of internationalisation and not its summation, as in the South. Setting aside the differing notions of internationalisation, some have now started to question the nature of the relationship which is being encouraged by academic mobility between the North and South. According to Laus (2012), who conducted research into North-South mobility, academic mobility (and partnership) is indeed one of the key elements characterising the internationalization agenda and relationship between Higher Education institutions of the Global North and Global South, but, the author goes on to suggest that we must try to understand the current process of international academic partnership as something which forms the basis for cooperation and 
must necessarily lead to a much deeper development. Presently, the North generally sets the agenda and there is clearly a need to rethink the system itself. International academic rankings and outputs in English favour the Global North to the detriment of the Global South, causing a series of difficulties for universities in the South. The current system is therefore biased towards the North and unless something is changed, the South will continue to be dependent on the North for "international cooperation and development". However, this is not to suggest that North-South partnerships and development are anything but of the highest importance.

The Great South must seek neither to encourage academic mobility alone nor continue with the focus of South-South regionalism, but must place itself truly on the global stage, forming networks, encouraging Global citizens and in so doing, embedding itself fully into the very nature of the process of internationalization of Higher Education, well beyond the restrictive notion of academic mobility alone. Rodrigues Dias (2015: pp. 61-62) who was Director of the Division of Higher Education of the UNESCO and Special Advisor of the Rector of the United Nations University, corroborates this when he writes that: "A final observation about Brazil can be applied to the other countries of the region. It is this country, vast in landmass, fantastic for its recent successes, but with immeasurable problems which are difficult to solve and are mainly to do with increasing differences between its citizens, that provides the setting for Brazilian universities. It is of little use wanting to "innovate" by adopting here, in its entirety, models that are applied in Australia, the United Kingdom, the United States, Europe. The university has to be strongly linked to society, to its surroundings. As it changes and changes rapidly, crisis becomes a part of its essence, and the university must permanently reform itself, it needs to change, adapt its action to new needs; in short: it must innovate. But, it must innovate with a view to a real society that needs to change for be better, to become more just, more democratic".

\section{References}

Appiah, K. A. (2008). Education for Global Citizenship. In D. Coulter, G. Fenstermacher, \& J. R. Wiens (Eds.), Why Do We Educate? Renewing the Conversation. The National Society for the Study of Education Yearbook for 2008, Vol. 107, No.1.

Aupetit, S., \& Escobar, V. (orgs) (2014). Internacionalizacion de la educacion superior y las ciencias em America Latina: Un estado del arte. Venezuela: Iesalc/Unesco.

Bellamy, R. (2000). Citizenship beyond the Nation State: The Case of Europe. In N. O'Sullivan (Ed.), Political Theory in Transition. London: Routledge.

Brackman, M. M. (2010). Internacionalização da educação superior e política externa brasileira: Estudo da criação da Universidade Federal da Integração Latino-Americana (UNILA). Dissertação (Mestre em Ciências Sociais), Porto Alegre, RS: Pontifícia Universidade Católica do Rio Grande do Sul. 270 p.

Clifford, V. (2013). The Elusive Concept of Internationalisation of the Curriculum. Oxford: Oxford Center for Staff and Learning Development, Oxford Brookes University. https://www.brookes.ac.uk/services/cci/definitions.html

Costa, B. S. (2014). Viagem de (auto)descobrimento: experiências de mobilidade 
estudantil de graduação no Programa Escala/AUGM/UFRGS. Tese (Doutorado em Educação), Porto Alegre, RS: Universidade Federal do Rio Grande do Sul. 231 p.

de Vita, G., \& Case, P. (2003). Rethinking the Internationalisation Agenda in UK Higher Education. Journal of Further and Higher Education, 27, 383-398.

https://doi.org/10.1080/0309877032000128082

Declaration of Foz do Iguazu (2015). In Forúm latino-americano de educação superior. São Carlos: Pixel. 343-357.

Deutsch, K. W., Burrel, S. A., Kann, R. A., Lee Jr., M., Lichterman, M., Lindgren, R. E., Loewenheim, F. L., \& Van Wagenen, R. W. (1968). Political Community and the North Atlantic Area. Princeton, NJ: Princeton University Press.

European Union (2012). The Development of European Identity/Identities: Unfinished Business.

https:/ec.europa.eu/research/social-sciences/pdf/policy reviews/development-of-euro pean-identity-identities en.pdf

European Union (2015). Internationalization of Higher Education, Brussels: European Parliament's Committee on Culture and Education.

http://www.europarl.europa.eu/RegData/etudes/STUD/2015/540370/IPOL STU(2015) 540370 EN.pdf

Feijó, R. N. (2013). A internacionalização da educação superior no Brasil: um estudo de caso de alunos estrangeiros do Programa de Pós-graduação em Antropologia social/UFRGS. Dissertação (Mestrado em Educação), Porto Alegre, RS: Universidade Federal do Rio Grande do Sul. 110 p.

Fligstein, N. (2008). The EU, European Identity, and the Future of Europe. Oxford: Oxford University Press.

Freeman, M., Treleaven, L., Ramburuth, P., Leask, B., Caulfield, N., Simpson, L., Ridings, S., \& Sykes, C. (2008) Embedding the Development of Intercultural Competence in Business Education ALTC Funded Project (Project Team Members: Mark Freeman and Lesley Treleavan University of Sydney; Prem Ramburuth University of New South Wales; Betty Leask University of South Australia; Lyn Simpson and Simon Riding QUT).

Green, D. (2007). The Europeans: Political Identity in an Emerging Polity. Boulder: Lynne Rienner.

Haug, G. (2010). La internacionalización de la educación superior: Más allá de la movilidad europea. En: MICHAVILA, F. (Dir.). Políticas universitarias para una nueva década [monográfico en línea]. La cuestión universitaria. N 6. Cátedra Unesco de Gestión y Política Universitaria de la Universidad Politécnica de Madrid.

http://www.lacuestionuniversitaria.upm.es

Henderson, H., \& Ikea, D. (2004). Planetary Citizenship: Your Values, Beliefs and Actions Can Shape a Sustainable World. Santa Monica, CA: Middleway Press.

Jesus, D. P. de. (2015). Educação a distância entre fronteiras: Cursos de graduação à distância brasileiros em Moçambique e a internacionalização da educação. Dissertação (Mestrado em Educação), Juiz de Fora, MG: Universidade Federal de Juiz de Fora. 131 p.

Keck, M. E., \& Sikkink, K. (1998). Activists beyond Borders. New York, NY: Cornell University Press.

Kling, L. F. D. R. (2013). Beyond Sea, Sun and Fun in Rio de Janeiro: Understanding EXchange Students Motivations and Interests 2013. Dissertação (Mestrado em Engenharia), Brasília: Escola Brasileira de Administração Pública da Fundação Getúlio Vargas.

Knight, J. (2004). An Internationalization Remodeled: Definition, Approaches and Ra- 
tionales. Journal of Studies in Higher Education, 8, 5-31.

Knight, J. (2005). An Internationalization Model: Responding to New Realities and Challenges. In H. de Wit et al. (Eds.), Internationalization of Higher Education in Latin America: The International Dimension (pp. 1-38). Washington DC, WA: World Bank.

Laus, S. P. A. (2012). Internacionalização da educação superior: um estudo de caso da Universidade Federal de Santa Catarina (332 p.). Tese (Doutorado em Administração), Salvador: Universidade Federal da Bahia.

Lazaro, L. M. (2016). Las organizaciones internacionales y las politicas educativas nacionales.

Leask, B., Beelem, J., \& Kaunda, L. (2013). Internationalisation of the Curriculum: International Approaches and Perspectives. In H. Wit, F. Hunter, L. Johnson, \& H. Liempd (Eds.), Possible Futures: The Next 25 Years of the Internationalisation of Higher Education (pp. 187-205). The Netherlands: European Association for International Education (EAIE).

http://www.academia.edu/10267470/Internationalisation of the curriculum internati onal approaches and perspectives

Menezes, R. G., \& Ribeiro, C. O. (2011). A cooperação Sul-Sul revisitada: A política externa do governo Lula da Silva e o desenvolvimento africano. In: Anais do I Circuito de Debates Acadêmicos CODE 2011, IPEA.

Monteiro, C. C. F. (2013). O ensino do design no Mercosul: uma proposta para a integração (187 p.). Tese (Doutorado em Desenho Industrial), Bauru: Universidade Estadual Paulista.

Morosini, M. C. (2015) Estado de conhecimento e questões do campo científico. Revista da Educação, 40, 101-116.

Nastácio, T. P. Z. (2014). Circulação internacional de estudantes dos cursos de graduação: O caso UNICAMP. Dissertação (Mestrado em Educação), Campinas, SP: Universidade de Campinas. 162 p.

Nilsson, B. (2000). Internationalising the Curriculum. In P. Crowther et al. (Eds.), Internationalisation at Home: A Position Paper (pp. 21-28). Amsterdam: European Association for International Education (EAIE).

Otten, M. (1999). Impacts of Cultural Diversity at Home. In P. Crowther et al. (Eds.), Internationalisation at Home: A Position Paper (pp. 15-20). Amsterdam: European Association for International Education (EAIE).

Robson, S. (2011). Internationalization: A Transformative Agenda for Higher Education? Teachers and Teaching, 17, 619-630.

Rodrigues Dias, M. A. (2015). Cooperação Interuniversitária em tempo de globalização uniformizante. In M. Morosini (Ed.), Forúm latino-americano de educação superior (pp. 33-66). São Carlos: Pixel.

Rodrigues, S. H. (2013). Jovens oriundos de Países Africanos de Língua Portuguesa na Universidade de Brasília: Experiências de migração internacional estudantil. Tese (Doutorado em Educação), Brasília, DF: Universidade de Brasília. 224 p.

Santos, C. M. A. (2014). Políticas públicas de mobilidade acadêmica internacional: Um estudo exploratório do dia a dia do aluno brasileiro na cidade de Lyon-França (336 p.). Tese. (Doutorado em Educação e em Ciências da Educação), Salvador: Universidade Federal da Bahia.

Sena, A. P. (2013). Internacionalização da educação e formação de capital humano e cultural: Estudos com alunos intercambistas da Universidade de Fortaleza (UNIFOR) (132 p.). Dissertação (Mestrado em Administração de Empresas), Fortaleza: Universidade de Fortaleza. 
Sigalas, E. (2009). Does ERASMUS Student Mobility Promote European Identity? Hamburg: ConWeb.

https://www.wiso.uni-hamburg.de/fileadmin/sowi/politik/governance/ConWeb Paper s/conweb2-2009.pdf

Silva, C. C. S. (2013). Mobilidade corpórea de estudantes internacionais: As motivações dos estudantes internacionais acolhidos por instituições de educação superior localizadas em São Paulo e Belo Horizonte (162 p.). Dissertação (Mestrado em Administração), São Paulo: Escola Superior de Propaganda e Marketing.

Sousa, A. D. de. (2015). O programa de estudantes-convênio de graduação na Universidade Federal da Bahia: Percepção dos estudantes oriundos dos Países Africanos de Língua Oficial Portuguesa-Anos 2009-2013. Dissertação (Mestrado em Estudos Interdisciplinares), Salvador, BA: Universidade Federal da Bahia. 119 p.

Tawil, S. (2013). Education for "Global Citizenship": A Framework for Discussion. UNESCO Education Research and Foresight (ERF) Working Papers Series 7, Paris: UNESCO.

UNESCO (2014). Global Citizenship Education: Preparing Learners for the Challenges of the $21^{\text {st }}$ Century. Paris: UNESCO.

http://unesdoc.unesco.org/images/0022/002277/227729E.pdf

Wallace, W. (1990). The Transformation of Western Europe. London: Pinter Publishers.

WCHE, World Conference on Higher Education (1998). Final Report.

http://unesdoc.unesco.org/images/0011/001163/116345e.pdf

Weale, A. (1991). Citizenship beyond Borders. In U. Vogel, \& M. Moran (Eds.), The Frontiers of Citizenship (pp. 155-165). Basingstoke: Macmillan.

Submit or recommend next manuscript to SCIRP and we will provide best service for you:

Accepting pre-submission inquiries through Email, Facebook, LinkedIn, Twitter, etc. A wide selection of journals (inclusive of 9 subjects, more than 200 journals)

Providing 24-hour high-quality service

User-friendly online submission system

Fair and swift peer-review system

Efficient typesetting and proofreading procedure

Display of the result of downloads and visits, as well as the number of cited articles

Maximum dissemination of your research work

Submit your manuscript at: http://papersubmission.scirp.org/

Or contact ce@scirp.org 